\title{
10
}

\section{Paths to knowledge}

\section{Connecting experts in oral histories and archaeology}

\author{
Karen L. Nero \\ Macmillan Brown Centre for Pacific Studies, University of Canterbury, New Zealand
}

\begin{abstract}
A long time ago people from Yap came to Palau for stone money. They used bamboo rafts to carry the money. The first time they came they went to one rock island and went under a hole [cave], to hide in the place to make stone money. That place had one house close to them with small children who cried all the time. One day the old lady took the children outside, going far from the house early in the morning, and then saw smoke from under the rock. She took the children home and told her daughter that she saw smoke under the rock. In the cave there was one Yapese who knew magic. That day he knew they had to kill the fire because he knew people might come and find us. And we were frightened. But the village chief was told, who told all his people to go look for smoke. He said if they found people, to call them to come so that we could know where they came from. And those Yapese killed the fire, but the chief came on top of the hole and called them and asked them to come outside and talk: 'I didn't come to fight. I want you to come outside.' When the Yapese came, they had brought plenty of food, so they took all their food, and gave it to the chief of the place. The chief asked where they came from - and they said they came from Yap. The chief asked why, and they responded 'we came here looking for stone money'. The chief said to come with his men and later to go look for stone money. And the place would be named for Yapese people.
\end{abstract}

Account by elder Yapese woman in Belau, 1991.

\section{Introduction}

The name of the village of Ngermid on the island of Koror in the Palau Islands is derived from Remith (Ngermid in Palauan), the Yapese word meaning 'place of hiding'. In the early 1990s, a Yapese female elder recounted this history to me, and it was then independently depicted for me in a contemporary wood carving (Figure 1) by a young member of a high-ranking Koror lineage. These oral historical and artistic performances demonstrate two of the media through which experts perform and thereby retain and transmit important histories over the centuries. The physical sites of these important encounters are still retained; bringing the appropriate elders to the sites will often elicit even deeper and more detailed accounts of the events that took place there, as they have been recounted over the centuries. 


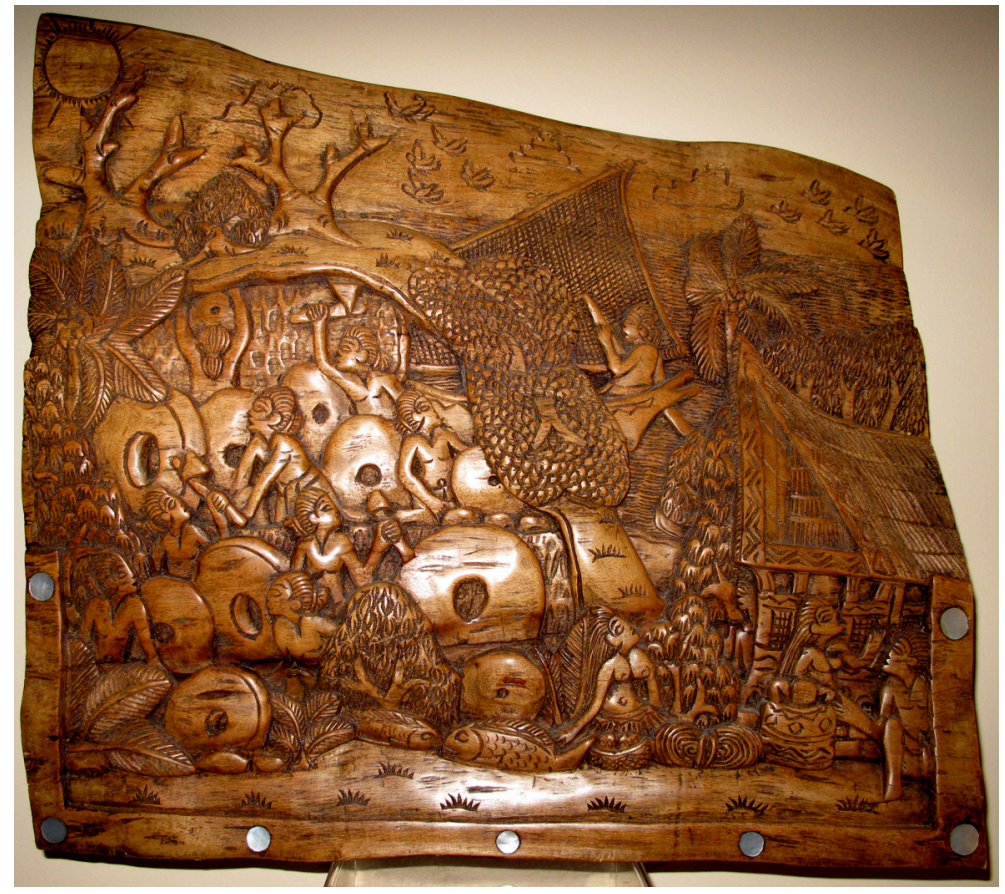

Figure 1. Storyboard showing the Yapese stone-money quarry, Ngermid.

Austronesian speakers separately settled the island groups of Yap and Palau in the Western Carolines. Roughly $450 \mathrm{~km}$ apart, the islands are situated just on the western edge of the Philippine continental plate, east of the Philippines and southwest of Guam in the Mariana Islands. Despite the designation of Palauan as a Western Austronesian language, and Yapese as an Oceanic Austronesian language, cognate terms for key cultural components in the two languages attest to long historical cultural exchange relationships connecting the two island groups, with especially strong ties between Koror in Palau and Yap. These historical relationships are maintained today through ongoing kin and marital linkages and close political and economical links connecting the Republic of Palau and Yap State of the Federated States of Micronesia.

Current archaeological research has confirmed settlement of Palau by at least $3100 \mathrm{cal}$. BP (Clark et al. 2006:215), and suggested that the original population was augmented but not replaced by later arrivals. Palauan oral historians refer to the ancient past as Er a Ititiumd or 'Mossy Past' (Nero 1987:38), evoking the image of stones covered by moss, by extension their knowledge not clearly visible. The flurry of recent archaeological work surrounding the construction of the Compact Road on Babeldaob (Wickler et al. 2005a, 2005b; Liston 2007, 2010) has provided a substantial body of data to support the development of more refined archaeological timelines (Masse et al. 2006; Liston 2009). Indeed, the term Er a Ititiumd might be an apt label for the era of early monumental earthwork that archaeologists call the Earthwork Era, with its moss-covered stones but few connected oral histories (see Liston and Miko, this volume).

The Rock Islands were permanently inhabited by about $1000 \mathrm{BP}$, with residents establishing sizeable stonework villages by about $700 \mathrm{BP}$, which eventually supported as many as 4000 to 6000 people (Masse et al. 2006:111-112). Most of the Rock Island villages were abandoned about 450 years ago. Occupation periods for the Rock Islands (including those off the shores of Ngermid, Koror and Babeldaob) may be helpful in establishing a timeline for Yapese quarrying, as oral histories in Palau and Yap agree that the Rock Islands were uninhabited when they were being quarried. Recent archaeological data from Omis Cave in Ngermid suggests that early Palauan settlers might have used it as a campsite. Fifteen charcoal and marine-shell samples from 
three Rock Island quarry sites, dated to ca. $300 \mathrm{BP}$, relate to intensive stone-money quarrying (Fitzpatrick 2002:239), supporting Descantes' (2005:94) analysis that quarrying intensified when European traders entered the region. There is still no conclusive data identifying the earliest dates that the Yapese might have first visited the Rock Islands for quarrying.

In this chapter, I consider the ways in which oral histories and archaeological data have been used to understand the early histories of the Palau islands and their relationships with the neighbouring island of Yap. I frame this reflection in the growing field of the study of experts and expertise, as a foundation of my discussion of Palauan and Yapese oral historians as experts, and the ways Palau's oral histories and its access may be structured - in ways some outside experts perceive as 'ill-structured'. I review definitions of key terms as they are generally used and open the discussion on how we might refine the use of these terms and their associated methodologies in conjunction with local oral historians. Summaries are provided of the characteristics of Palauan oral histories, and the protocols used in the 1980s research on Koror's oral histories. While the type of information available through oral histories differs from that of archaeology, a fruitful area of consideration is that of identifying relative sequences of events. I discuss excerpts from a few of the Yapese and Palauan oral histories, demonstrating how historians indicate the relative order of key events, and identifying potential ambiguities in trying to relate these to chronological time. I conclude with discussions of recent studies of Yapese stone-money quarrying as examples of archaeological approaches to integrating knowledge from the oral histories, in order to help identify ways in which the two disciplines might better work together. I have grounded these analyses in the Palauan histories with which I am most familiar, while recognising parallels with work done elsewhere in the Pacific (i.e. Burley 1998; Sheppard et al. 2004). These reflections should not be taken as a general discussion of oral historical protocols and practices as there are variations within Palau.

Throughout the chapter, I use Palauan metaphors such as the iek (bead money necklace) and the term rael (path) to communicate some of my understandings of the characteristics and practices of Palauan oral histories. Rael, one of the key Palauan icons, refers to the trails that connect villages, and serves as a multivalent reference to the social relationships established between groups and political units by past events, or also a method, strategy or pattern (see Parmentier 1987:109). Both archaeological and oral historical approaches offer different types of information useful in understanding the early settlement periods. After the disastrous depopulation of Palau from an estimated 50,000 people before European contact and introduced diseases, to 3743 people by 1900 , we are fortunate that contemporary oral historians still retain and transmit some of these early histories (Palau National Committee on Population and Children 1997:7). Archaeologically based timelines may indicate the potential temporal depth of the oral historical records, while oral historical accounts focus on key actors and their local and inter-island relationships over time, including the relative order of key events. Often these oral historical and archaeological accounts appear to complement rather than contradict each other, and suggest that coordinated studies could be effective. The training of indigenous ethnographers and archaeologists should deepen the types of questions that could be addressed.

In the early 1980s, at the request of the current Ibedul of Koror, I worked with the chiefly councils and staff to record the oral histories of Koror and its constituent villages. Koror (in Palauan Oreor or Sureor, or the poetic name Erengul) is the official English name of the island, a state of the Republic of Palau and one of two paramount chiefdoms. At that time, although secure in their oral histories that reached deep into the past, the historians could not be certain of Koror's calendrical time depth or whether some of the cultural sites might have been made by people other than their own ancestors. In the 1970s and 1980s, most archaeologists and 
historians were reluctant to seriously consider information from the oral histories, as indicated by their labelling of the period before written documentation, as prehistory and those histories not personally witnessed as oral traditions. In the early 1980s, Bruce Masse and David Snyder, of the Center for Archaeological Investigations of Southern Illinois University at Carbondale, undertook archaeological research on Koror, under the direction of George J. Gumerman (Gumerman et al. 1981), partially overlapping with our oral historical research. By the mid 1980s, their team provided us with preliminary archaeological assessments of the dates that the Rock Island villages had been abandoned (Masse 1984; Masse et al. 1984). These dates, up to 400 years ago, were compatible with preliminary dates suggested by the sequence of the Rock Island village wars recounted in the histories. This cross-verification supported an argument that some of the Koror oral histories had a depth of perhaps 400 years - a time depth then not generally acknowledged by academics.

This led me to seek other forms of independent verification of oral histories: the early Yapese quarrying in Palau provided an excellent case study. Colleagues from the Yap State Historic Preservation Office and Palau Resource Institute, with whom I was working on a separate project, supported my suggestion to seek oral histories both on Yap and Palau about the early stone-money quarrying, and we were able to interview elders of both island groups.

Today's oral historians are carefully considering the histories that were passed on to them and how they might be best interpreted. After several decades of collaborative work by Palauan and outside researchers through the Palau Bureau of Arts and Culture, the Belau National Museum and the Ministry of Cultural Affairs and the increasing cadre of Palauan researchers trained in both Palauan and Western methodologies of cultural anthropology and archaeology, there is renewed excitement in researching the histories of the islands. The expertise of archaeological studies is welcomed as it provides a second 'path' (rael) through which knowledge may be augmented. Both disciplines, with their very different theoretical and methodological approaches, may offer insights that will create a more complete vision of the past.

Our research on early Yap-Palau stone-money quarrying coincided with preparations to hold the 8th Pacific History Association (PHA) conference on Guam in 1990 (see Rubinstein 1992), when organisers and participants sought new ways to access and integrate indigenous scholars and their knowledge into the early histories of the Pacific nations. We hoped to open up academic practices to include appropriate consideration of the local histories of the region and avoid undue reliance on documents often written after brief chance encounters during the early contact period. The papers from the 1990 session Oral Traditions and Alternate Media, co-chaired by David Hanlon and myself, are especially relevant to this chapter. Pohnpeian archaeologist Rufino Mauricio, then a graduate student, demonstrated how oral histories recorded and published by early researchers might be best understood through identifying the framework of indigenous Pohnpeian types of historical knowledge (what we might call genres) and the expectations the historian or the audience might have of the different types of narratives. Mauricio's (1992:239) paper is a major contribution towards inter-disciplinary studies and the ongoing work to bring archaeologists and oral historians into closer understanding of each other's work and to begin to integrate these approaches.

Cultural-knowledge custodians, anthropologists, archaeologists and historians continue to seek inter-disciplinary approaches. The conference, Pacific Island archaeology in the 21st century: Relevance and engagement Dikesel a Beluu, supported by the World Archaeological Congress, was held in Palau in June 2009. Dr. Rufino Mauricio, Chairman, ICOMOS Pacifica; Director, FSM National Historic Preservation Office; and Secretary General, FSM National Commission on UNESCO, was a keynote speaker. The session, Archaeology, oral traditions and the history 
of the past in the Pacific Islands, convened by Dr Christophe Sand, helped identify current challenges and ways forward. Members of our Dikesel a Beluu academic and community audiences were enriched by the insights of the increasing numbers of indigenous anthropologists and archaeologists directing this research.

\section{Experts and expert systems of knowledge}

I begin with the premise that the Palauan and Yapese oral historians are experts. They, like archaeologists, are formally trained in the theoretical and methodological approaches of their disciplines, the protocols under which they are practised, and rigorous verification processes. Their approaches and the types of data that archaeologists and formally trained oral historians collect, analyse and interpret differ substantially. While at times these interpretations may differ or clash (as they do on other Pacific islands), on Palau they may provide a more complete foundation to understand past events.

By definition, an expert is a 'person having special skill or knowledge', and expertise as an 'expert opinion or skill or knowledge' (Concise Oxford Dictionary 1964:426). Cambridge University Press has recently published a handbook of the new field of scientific research on expertise and expert performance (Ericsson et al. 2006:3, 4) that states 'expertise then refers to the characteristics, skills, and knowledge that distinguish experts from novices and less experienced people'. The handbook 'includes a multitude of conceptions of expertise, including perspectives from education, sociology and computer science, along with the more numerous perspectives from psychology'. The definition is thus limited for our purposes, as it does not include nonWestern or indigenous perspectives, and fails to draw on the disciplines of anthropology, history and indigenous studies. Nevertheless, I believe that positioning this chapter within the framework of the study of experts and expertise may provide new perspectives and widen the discussion between anthropologists and historians, and cultural anthropologists and archaeologists.

The chapter by psychologists James F. Voss and Jennifer Wiley, Expertise in History, is grounded in Western approaches and reliance on written sources. They believe 'an expert in history is assumed to have a general and specialized knowledge of history as well as facility in the skills of historical research and writing', although paintings and objects are included among the otherwise written resources that might be 'examined for their reliability, validity, authenticity and usefulness' (Voss and Wiley 2006:569). One might question the utility of their division of the domains in which expertise may be formed into two types. The first 'because of their conceptual evolution, permit the use of mathematics, formal logic, or well-controlled experimentation ... are termed 'well-structured', frequently dealing with problems having a single answer, readily identifiable constraints, and agreed-upon solutions'. The second domain is 'termed 'illstructured', having more than one possible answer, requiring identification of constraints, and having no agreed-upon solution'. Political science and history are used as examples of this latter type of domain that has 'conceptual structures that allow relatively little opportunity to use mathematics, which leads to relatively less certainly in subject-matter in knowledge and more heterogeneity in constraint usage' (Voss and Wiley 2006:569-570). However, the authors do conclude that the expert historians' 'subject-matter knowledge' - [is the area in which] 'virtually across all domains, our understanding of the development of such knowledge is inadequate, in history as well as other domains. Longitudinal studies of knowledge development are especially needed ...' (Voss and Wiley 2006:581).

The study of the development, retention and transmission of oral historical knowledge by recognised specialists could make a substantial contribution to the study of experts and expertise. John Wilding and Elizabeth R. Valentine's (2006:539-552) chapter on Exceptional 
memory reviews some of the universal foundations of exceptional memory, including 'semantic' memory or a body of information embedded in an organised structure that is added to and organised over a long time; 'episodic' memory, or 'the ability to reproduce a prior input, event, or episode'; and 'loci', a mnemonic device that relates to its Latin root locus for place or location. The Carolinian, and other, oral historians demonstrate exceptional memory skills, such as the ability to retain and reproduce verbatim an oral account or instruction. Interestingly, Wilding and Valentine noted that using functional MRIs to understand the neurological basis of superior memory provided: 'no differences in any aspect of the brain recordings to match the differences of the experts for the different materials' (Wilding and Valentine 2006:548).

\section{Palau's expert historians}

In 1979, at the time of my early research in Palau, Malsol Ngiraibuuch Ngiraklang was recognised as the pre-eminent historian of Palau. This was true structurally as he held the title Ngiraklang, one of the high-ranking titles of Imeiong in Ngeremlengui. Imeiong, as the eldest stone son of the goddess Milad of the current world, was responsible for holding the histories and sacredness of Palau (Parmentier 1987). Ngiraklang was an expert in all aspects of Palauan history and a master fisher and expert on the land and seascapes of Palau. He was legendary for his exceptional memory and ability to recall verbatim a new account he had heard. Nor was his reputation limited to Palau or Yap; he became an internationally recognised expert after Robert Johannes (1981) published his seminal Words of the Lagoon on Palauan marine resource management, based on his work with Ngiraklang and other Palauan master fishers. Ngiraklang was the primary mentor for at least five international doctoral theses in different social and physical science disciplines. While pre-eminent, he was only one of Palau's expert male and female historians. The senior male and female elders of Palauan lineages and villages serve as custodians of the histories. Today, each of the 16 states in the Republic of Palau selects a historian as a representative to the Palau Society of Historians. The systems of knowledge the historians preside over are quite structured, involving many different levels with restrictions that may be opened in turn depending on the person seeking and the knowledge levels already attained. Age, clan and village affiliation, and the context and reason such information is sought may also affect access. Such restrictions may serve to protect the integrity of the oral histories, and may help ensure their transmission. Yapese similarly identify respected male and female historians.

\section{Terminology}

The use of certain key terms differs for members of the public and within disciplines. Through the lens of a cultural anthropologist working at the interface with history, I summarise the way in which I understand and use the terms oral histories, oral traditions, ethnohistory and prehistory and their relationship to the larger field of history. The dictionary definitions of terms ${ }^{1}$ reflect the common Western bias towards written documents, and a polarisation of Western and nonWestern peoples which is questionable in academic levels of discourse. It will need the combined efforts of the broader discipline of anthropology to influence and update public perceptions and biases.

Jan Vansina (1985:3-32) distinguished between oral histories and oral traditions on the basis that oral histories are based on memories of events witnessed by the person narrating them, limiting their range to the age of the oldest living individual. A series of individuals might be interviewed to access multiple accounts that could be compared with each other and other accounts, and permit initial assessments. The Oxford Dictionary of English draws on his work 
in its definition of oral history as 'the collection and study of historical information using tape recordings of interviews with people having personal knowledge of past events', retaining the primary requirement of personal experience, but adding the requirement that the account be recorded. Vansina used the term oral traditions to refer to accounts of those that were no longer contemporary, in turn subdivided between memorised traditions, and a number of different types of narrative accounts.

Vansina's (1985) work has been highly influential in the study of oral histories. He carefully identified the requirement that all accounts must be submitted to evidential questions in order to assess the value of a particular oral history or tradition. For its time, Vansina's research was innovative - encouraging scholars to consider the historical and cultural relevance of oral traditions. However, the debates have shifted as anthropologists and historians attempt to take these issues into account and work across disciplines (see Dening 1980; Sahlins 1983, 1985, 2004; Ohnuki-Tierney 1990; Biersack 1991; Comaroff and Comaroff 1992; Merwick 1994). It is time to reconsider how we might try to understand the various types of historical accounts, how they are meant to be used and understood, and whether these types or genres have any comparative validity.

I use the term oral histories simply to refer to any account verbally transmitted to another individual or group of people. For those engaged in learning oral histories, this term is considerably expanded below. I suggest the critical aspect of this type of history is that it covers a body of knowledge that is orally transmitted by recognised experts and that has been retained and transmitted over time by these oral historians. Access to oral historical accounts (including different types of accounts or genres) is often restricted but not closed. The distinction of personal witness may still be marked. A Palauan historian will preface the account of an event he or she witnessed with the statement: 'I saw this with my own eyes.' This gives the account a certain credibility, although of course, different witness reports might vary. There are a number of different types of oral histories that might be performed: in Palau, these include a chant, dance performance, verbatim memorised account, narrative that may be interrupted, proverb, or reference to a material sign of the event in the form of a stone or bead money or low-relief carving on a beam of the community meeting house (bai). In all cases, it is the oral historian who provides the necessary connections and interpretations. In the case of the lineage, village or state histories, the Palauan historian is entrusted to retain and appropriately pass on the story on behalf of the collective dui (title) he or she holds. This identification with past titleholders is often marked by an oral historian's use of the plural pronoun and present tense to describe events in the past. They often specify the relative order of events in the narrative, and certain place names or titles may indicate relative antiquity. It is important to foreground the oral historian as the source of the knowledge and its interpretation, not the recorded or written narrative.

I use only the term oral history to refer to all histories that are transmitted orally because personal witness may not be the most important characteristic of these differing types of oral histories, and as a reminder that all oral (and written) histories are subject to potential distortion and culturally appropriate verification.

I prefer not to use the term prehistory ('the period of time before written records; myths that stretch back into prehistory' according to the Oxford Dictionary of English), as it is clearly rooted in the requirement that history begins only with the availability of written accounts and by association only when Europeans enter the Pacific. Common in early accounts, today's Pacific archaeologists rarely use the term. Early accounts of Pacific peoples and places were generally based on very recent, partial and often biased observations that visitors recorded during brief 
visits that were often characterised by limited opportunities for good communication with the people visited. Indeed, Palauan oral histories recognise that Portuguese (Ritzenthaler 1954:11) and Spanish visits preceded that of Captain Wilson and his crew, who provided the first written account of their three-month stay in 1783 (see Nero 2002). All accounts must be subjected to assessment, in particular of length, breadth and depth of observations and the opportunities for communication across languages. While a demarcation of major transformations as a result of interactions with significant and often powerful outsiders is important, it should not be used to suggest that historical knowledge was not retained by the local peoples before the arrival of these most recent outsiders.

The term ethnohistory has a long controversial history as used by cultural anthropologists, historians and archaeologists. The general Oxford Dictionary of English definition of ethnohistory as: 'the branch of anthropology concerned with the history of peoples and cultures, especially non-Western ones' goes back to Dening's (1966:23) early discussion and distinction that 'We write the history of whites and the ethnohistory of the rest', despite challenges to such a conceptualisation as a form of intellectual apartheid. Anthropologists and historians have worked since to bridge their theoretical and methodological differences, best captured by Dening's (1980:35-44) historical review of the term's use, followed by his eventual strict limitations on how the term might appropriately be used (Dening 1991:347-377). I am aware of the long debates, and the importance of this disciplinary designation combining ethnology and history to study America's First Nations peoples in particular. While I support all theoretical and methodological developments in formal training on how to do oral historical research and how to relate it to ethnology, history and archaeology, I still find the term counterproductive (see Chaves 2008 for a current review). Some sub-disciplines and academics still use the term to refer to early written traveller accounts; this appears to compound the error of preferring early written accounts by outsiders. Others use the term to refer to oral histories. I suggest we need to reconsider academic uses of the term ethnohistory as a sub-category of the disciplines of history or anthropology to refer to the study of peoples and cultures without written histories, generally not according to the understandings and practice of the mainly non-Western peoples being studied.

I have used the term oral history to draw attention to the live performance and transmission of knowledge to one or more individuals, We must refine our methodologies to consider the effects of the audience, event, place, and context or query to which the historian was responding in a particular presentation. Each of these factors may influence what the historian chooses to include, emphasise, or exclude. While a written account of an oral presentation may later be produced from notes or recordings, such an account is not the same as the original presentation. We must sharpen our methodologies to capture and deal with these differences. In many of the definitions discussed above, there appears to be an underlying assumption a) that the oral history has been recorded and/or transcribed into a written account, and b) that the oral and written account may be considered the same. Any public speaker differentiates between oratory, in which Pacific elders excel, and a polished written account. Expert anthropologist, writer and lecturer Gregory Bateson insisted on this important differentiation: he permitted members of the audience to record his lectures or seminars, but not to transcribe them. He reserved the right to control and change the language of oral presentations to language appropriate for general or academic publication (Bateson seminar, 1982).

Translation is a critical issue for those working with indigenous histories. Oral histories often require access to local specialised vocabularies and an understanding of the specialised language of politics (Peterson 1990), including the identification of and access to multiple layers 
of appropriate meaning. There are many reasons why a written transcription/translation of an oral history must not be taken as a stand-alone resource document.

As we strengthen relationships with indigenous scholars, some of the basic premises may be adjusted. It seems that a history seeking to understand a people and place remembered through oral histories, the landscape and material signs, and architecture and performances needs to begin with the premises that:

- there are expert knowledge systems retained by peoples and cultures who may use other media for the retention and transmission of historical knowledge, which may or may not have been partially transferred to written accounts in the past several centuries;

- indigenous oral historians are the experts and any written accounts of the oral histories (that are generally partial) should not be used independently without consultation with those who speak for the histories;

- the different theoretical bases, accepted methods and expertise of archaeologists and oral historians must be respected; and

- we must find ways to engage with different types of knowledge and verification.

\section{Reflecting on oral histories}

While the oral histories are primarily held and transmitted by the appropriate lineages and villages, at the regional level the Micronesian national and state historic preservation offices have the responsibilities of recording and preserving the histories and cultural knowledge. They often have the difficult task of mediating between oral historical and archaeological approaches. The following summaries are offered of some of the characteristics, structures, types and protocols that might be useful as an introduction to outsiders. This is necessarily incomplete as access to certain levels of knowledge or specific details is only given based on the oral historian's assessment of the knowledge and understandings of the protocols and the reasons why such information is sought. While this may limit cross-cultural understandings that could be relevant to theoretical work on the roles and responsibilities of experts and the structure and protocols of historical knowledge systems, I also recognise that these protocols are followed to protect and manage the integrity of the knowledge.

\section{Characteristics of oral histories in Palau}

Palau and Yap's multi-layered oral histories range from highly accessible short stories told to children, to the guarded lineage and village histories, some so strictly limited that they require a code for access. In my doctoral thesis, I used the image of the Palauan iek (a necklace of Palauan bead money, Figure 2) as a metaphor for oral histories. These valuables are considered male money, although only women wear the necklaces. While individuals earn bead monies through service, lineage elders control how they may be used and occasions when they might be worn, and by whom. The composition of the beads on a necklace is based on the ranked relationships of the individuals who brought the money into the house, the values of the various pieces, and a sense of balance and aesthetics. Experts know the stories of the named high-ranking individual monies, and the histories of their transfers. This bead-money necklace thus embodies the multivalence of the oral histories, with their discrete units of different types, values and histories; the control of the pieces and the histories by the elders; the proper ordering of the pieces; the emphasis on social and spatial relationships; the limited occasions when necklaces are to be seen or their histories discussed; the physical grounding and representation of social relations 


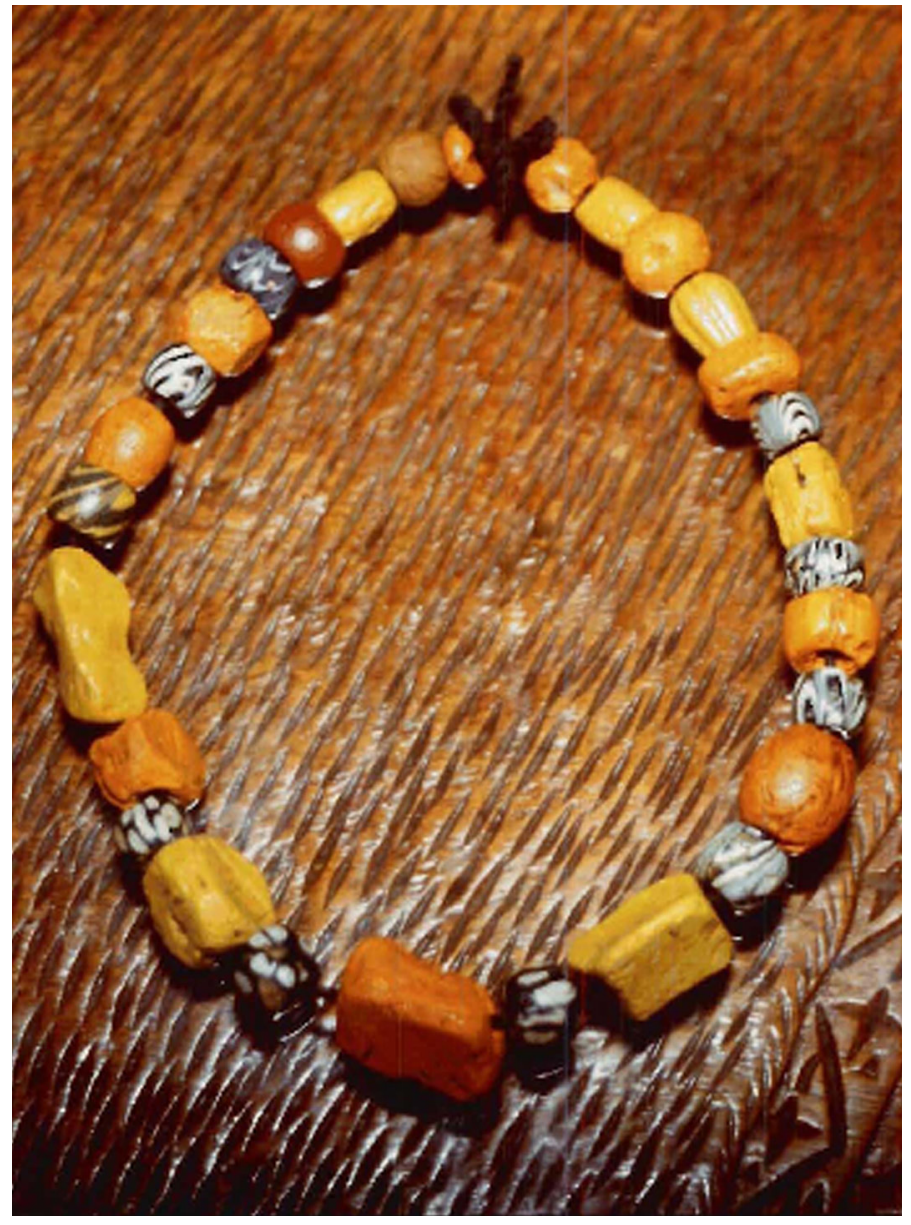

Figure 2. lek: A metaphor for oral history.

and histories; use of mnemonic devices; and the prestige and power based in the control of knowledge (Nero 1987:20-22).

Small oral versions of important histories are well known - for instance, the love story of Osilek (chief of Ulong) and Oreng. At its chiefly levels, this history expands to provide more details and refer to other Rock Island village histories, love relationships, wars and migrations. Histories are linked from the clans/lineages to the series of polities that range from the small villages comprising the districts to the wider village federations and two paramount chieftaincies. The male and female elders of the lineages and villages have the rights to and are responsible for appropriately transmitting the histories, and selecting the level of information suitable to the occasion and audience. That there may be different 'variants' of stories largely relates to the occasion, and the kin position and knowledge level of the person to whom the information is transmitted, similar to the highly structured protocols for the transmission of knowledge among Yolngu (Morphy 1991, 1995). Care is taken that the appropriate elder speaks. To ensure its proper transmission, however, different levels of the story are generally more widely known by clan members and elders, partly to ensure their continuation. All societies restrict access to some types of knowledge and information by law and practices. This appears to especially be the case in Pacific societies that rely strongly on oral histories and therefore maintain control over how such knowledge is transmitted and verified (see Kesolei 1977; Meleisea 1987; Hanlon 1988; Petersen 1990, 1994; Morphy 1991; Mauricio 1992; Schwarz 1997; Tellei et al. 2005).

Kesolei's paper (1977:4-11) identified attitudes and practices that might affect access to Palauan knowledge: information is restricted; there is an unwillingness to make their knowledge public; the proper person must be asked; opinions of Palauans are more important 
than those of foreigners, affecting how such information might be received until verified; and Palauans are protective of close relations and fellow villagers. These issues affect local as well as outsider researchers. Members of the Palau Resource Institute (PRI) worked successfully with archaeologists on part of the Compact Road project, and noted: 'sometimes access to traditional information does not come easily' (Tellei et al. 2005:12). The restrictive protocols to protect the proper transmission of verifiable histories raise barriers to access unless historians are carefully approached. The proper identification of the appropriate person with the knowledge and position to speak for the history is paramount. As noted by Kesolei (1977) and Tellei et al. (2005), this knowledge is generally grounded within a lineage/clan or village. It is common for either a knowledgeable elder or younger clan members to refer the researcher to the person who speaks for the history. Once the proper person has been identified by the local chief and other contacts and confirmed by the Palauan Society of Historians, the research path may be smoothed (Tellei et al. 2005).

\section{Genres}

It is useful to consider the types of oral histories and stories that may be recounted and their specific characteristics. In the Koror histories, we encountered several types of histories that followed different levels of protocols and access. I will leave the characterisation of Palauan oral historical genres to a Palauan scholar, but as an analogy, I summarise from Mauricio's study (1992:362-363) of Pohnpeian genres in which he attempted to understand the ways in which the people of Pohnpei might have understood Hambruch's $(1932,1936) 1910$ requests for their oral traditions. Some of the histories he collected would have been 'stories of Pohnpei' (folk tales, legends, life histories), or 'details of Pohnpei' (applied or practical knowledge of social behaviour and specialised technological skills). The latter are necessarily susceptible to relatively short-term change and are more descriptive and less explanatory. In contrast, the 'content of Pohnpei' is comprised of subgroups of histories of the land and the people. Considered sacred, these are interpretive accounts that are much more subjective and generalising: 'Authoritative explanations are a prerogative of the senior oral historian' (Mauricio 1992:363). The final category is the 'sacredness of Pohnpei' (i.e. spells, magical or sorcery formulas, esoteric changes, medicinal knowledge). These are highly guarded, not normally disseminated, and characterised by archaic terminology suggesting (Mauricio 1992:363):

... that they have remained lexically intact over a long period of time. The majority of them are neither descriptive nor interpretive in nature. Rather, they are believed; they are thought of as possessing manaman (a form of detached authority, force or supernatural power).

To my understanding, a similar set of descriptive, interpretative and apparently unchanging types of oral histories exists in Palau. I believe that for Palau, what Mauricio discussed as the 'content of Pohnpei' histories might include histories of the land, villages and peoples of Palau and would include bodies of historical knowledge from which historians might draw in responding to specific questions or events (i.e. be more interpretive). This might also include Palau's memorised verbatim histories that may be of great antiquity and carefully controlled; these would not be altered during their performance. Yet they might not be part of what Mauricio included as the 'sacredness of Pohnpei', which would include some of the older chants in archaic language. I note that Parmentier (1987) specifically used the term 'sacredness of Palau' in his work on the oral histories and the role of the historians of Ngeremlengui in maintaining this. There are complex analyses to be made, and this discussion suggests caution for non-specialists in interpreting and categorising written accounts. 


\section{Protocols followed in oral historical research in Palau}

As a researcher employed by Palauans and working under their direction, I was taught some of the protocols governing research in Palau, first by Palauan anthropologist Katharine Kesolei and the staff and board (1979-1982) of the Palau Community Action Agency. ${ }^{2}$ I observed the care with which elders opened all meetings by acknowledging those present, explaining the purpose of the research to be undertaken and asking their permission and support. Care was taken to ensure a proper mix of researchers with kin or village linkages, both elders and more junior workers, and gender balance. Initial research results were reported back to the communities for clarification and comments, and at times spurred lively debates. Extreme care was taken to check data and interpretations.

In 1982 at the request of Ibedul, I was part of a Koror oral histories project under the auspices of the chiefly councils of central Koror (ordomel, the spear head): Ngarameketii (male), Kerngab (female), and Rubekulkldeu (the highest-ranking male chief of each of the constituent renged - or tied villages of Koror). ${ }^{3}$ This research focused on the village/state histories of Koror (Erengul), one of Palau's two paramount chieftaincies, including its consolidation in the late 1600s and early 1700s. ${ }^{4}$ I worked in a counterpart relationship with then Kloteraol Alexander Merep, who had just returned to Palau after completing his master's degree in political studies in the United States. As the holder of the title of Kloteraol he had the responsibility to speak for the beluu (village) within the Ngarameketii council; these oral histories were thus transmitted orally to an appropriate titleholder. Koror State staff members assisted in recording, transcribing, at times providing translations and seeking the meanings of special terminology.

To an outsider, it might appear that the Palauan history so collected would necessarily be of the elites. While the recording of village histories tends toward that (Sahlins 1985), in Micronesian societies chiefly council members generally represent clans of all ranks. In Palau, each of the chiefly councils is comprised of the selected titleholders of the 10 major kebliil (normally poorly glossed as 'clan' in English) of the village. Each of the titles holds specific responsibilities within the council. In turn, each of the renged (tied) villages are governed by their respective male and female councils, and the highest male titleholder of each of Koror's renged form the Rubekulkldeu council under the direction of the Ngarameketii. ${ }^{5}$ Normally, the oral histories are held by the senior male and female titleholders of each of the lineages/clans and jealously guarded within these units; quality control is maintained through limiting who has the right to speak the history. Younger members learn the histories at levels appropriate to their position and aptitude. This is true both for the central villages and for the Rubekulkldeu villages that had existed before the consolidation and creation of the new polity of Koror. The villages recounted their long histories before the establishment of Koror, and their particular entitlements, rights and responsibilities were confirmed as they joined the new federation of Koror (Erengul).

The histories of the ordomel and renged villages and the histories of their past and present relationships were recorded. It was the responsibility of the senior male and/or female titleholders to speak the history of that village and clan; in each case, we were directed to those elders who could speak (and verify) the relevant histories. While we followed a template of interview topics, each historian chose what information (at what level) would be recorded. Some of the historians chose not to discuss details of the village gods. A male elder was often accompanied by his wife and/or by female clan members who would join the discussion. When we were interviewing female titleholders, the male transcriber generally did not accompany us, so that when Kloteraol did not join us the interviewee's daughter or other female relative often translated my questions 
into Palauan. With the exception of one bilingual titleholder who chose to speak in English, the interviews were conducted in Palauan. In the process of transcribing the interviews, our skilled transcriber at times encountered Palauan words that were not in general use. Where possible, these words were explained and translated into English by one of the respected Koror staff members, or a former educator, or, if necessary, referred to other language experts. All those interviewed could decide whether the interview or any of its parts should not be recorded.

Our interviews varied by the topic and genre of material presented. Some of the old histories were told as performances, often using archaic language and recited without interruption. Other topics elicited a lively interaction as a way of assessing the interviewer's knowledge, and at least one follow-up interview was generally required to clarify and extend discussions and check possible interpretations. We held interviews at relevant sites to spur memories of past events, such as the Ngarameketii or Ngerkldeu meeting houses, titleholders' houses, or village or Rock Island sites.

A factor not always considered when reading written documents of interviews or events relates to the dynamic between members of the audience and the oral historian. As noted by Kesolei (1977), a historian might not wish to share particular knowledge with those present. The social characteristics of the interviewers (clan/village affiliation, ties to the person interviewed, knowledge level and especially age) affected the dynamics and presentation of the story, especially in the more interpretive genres. The presence of a particular person could elicit or preclude certain stories. Knowledge may be provided only for information but not further dissemination.

Appropriate historians may be able to verify or query accounts, although the type of history may affect this. Some of the village histories were verified by the appropriate knowledge holders at the time in a joint interview with village titleholders. Certain types of questions are better pursued with a single or a few historians. Rarely, we were advised to seek an appropriate historian to melediich or 'shine the light' on a sensitive issue. Multiple sources - a physical sign, a chant, or a dance depicting an event - may also be used to verify accounts. Some chiefly kelulau or 'secret or sensitive political matters' were raised; in one case, the historian advised that we could hear and record but not write the kelulau.

Even if an interview is carefully conducted according to appropriate protocols, the histories so recorded may not fully reflect the knowledge of the historians. First, historians carefully responded to a question as it was presented, which might not have elicited all the knowledge they held on the topic. Second, the historian's knowledge of a history is often multi-levelled in both the ways it is transmitted and the ways it should be used. The historian will choose the level on which to respond, if at all. Even when in agreement with the stated purpose, the historian might not reveal the level of his/her knowledge on a specific topic.

As with all historical sources, oral histories must be used carefully. Today, interviews are often kept in tape or digitised form, and many are transcribed in the language of the historian. A very serious consideration is the language the interview was originally in and how and why it may be translated. In Palau, where both English and Palauan are official languages, English is increasingly used in documents, even though glosses only incompletely 'translate' the concepts of the original language. A written account of a Palauan history might only have been 'partial' when recorded, some of its meanings might be lost in translation, or the reader's understanding might differ depending on the version read. Translations and back-translations will not easily resolve the difficulties.

Koror's histories were transmitted orally, recorded and transcribed, as were major events of the polity and its governance during this period. Protocols for recording Koror's oral histories were carefully followed. Information and interpretations were verified both in the process of 
interviews when multiple experts were present, and through subsequent interviews. While to a large extent these protocols mirror those generally used by socio-cultural researchers, when seeking privileged histories in Palau close attention to the protocols is critical to the quality of the knowledge shared. It is through these protocols that trust may be gained so that, in conjunction with cultural expectations, the oral historian understands the purpose of the research and the ways the information will be used. The Koror state-level research was possible only because it was done for the State of Koror. ${ }^{6}$

\section{Oral historical accounts of early Yap stone money quarrying: Yap and Palau}

We are fortunate that the oral historians of both Yap and Palau retain histories of the early political/economic activity of stone-money quarrying. Accessed independently, the histories agree on key issues important to island histories, such as identification of named money pieces presented from Rul to Koror and from Gachepar to Melekeok to confirm quarrying rights and to illustrate the significance of place names in indicating relationships.

I believe that the careful consideration of a variety of historical sources can supply a framework by which the 'snapshots' provided by outsider-written descriptions may be interpreted. In using these various media, I suggest two controls to test the reliability of the data:

- Within each island or polity, using indigenous tests of the reliability of sources, as well as more locally based tests such as the conjuncture of chant, stone record, and/or money piece - the latter of which, in Palau, validates important histories (see Parmentier 1987:12).

- Between islands or polities, verification is provided by using independent sources that relate to the same subject.

\section{Yapese and Palauan oral histories of early stone-money voyages}

\section{Yapese histories}

When Yapese and Palauan elders are asked about the histories of their relationships with other peoples before the European ships came, they turn to the stories of the transactions of valuables between the leaders of the two islands' polities. According to a Yapese money expert, in the beginning Yapese and Palauans used similar forms of money, a single piece worn on a necklace by the wives and daughters of the chiefs, as Palauan women wear them today, or kept in purses. The beads were of many materials, some glass, others stone or clam shell, and in many different colours. $^{7}$

\section{The opening: Ngermid history}

The brief oral history quoted at the beginning of the chapter describes a very early visit by Yapese for quarrying stones to craft into a form of money. I believe this account refers to what is called Omis Cave in the archaeological studies of Fitzpatrick (2001, 2003), discussed below, and other oral histories. The Yapese elder's daughter translated her account into English during my interview, a language common to Yapese, Palauans and myself, and from which a written account was made and excerpted. This history provides an important record of the origin and meaning of the name Ngermid and documents the gifts of food used to establish friendly relationships between the Yapese and the chief of the village in order to secure his permission to quarry the stone needed to make money. The elder uses the personal plural, demonstrating her incorporation of the ancestors for whom she is speaking into the story, an important characteristic of traditional accounts in many societies. She refers to the Yapese use 
of magic and the Yapese fear of discovery (not always communicated in accounts by males). The name 'Ngermid' provides a time marker, albeit ambiguous.

Ngermid is one of the ancient villages of Belau from the time of Chuab (Nero 1987:185; Liston and Miko, this volume). It has its own side village division and two chiefly councils, and elders still point out the cave site associated with this story. The identification of Ngermid as an early site for stone-money work and the account of the direct relationship between the chief of Ngermid and the Yapese are important in suggesting that these might have occurred very early in the cultural sequence. It would be useful to establish tentative dates for this important inter-island network. These exchange networks as early international relationships, and the production of monetary valuables are long recognised as key to political development, especially of chiefly hierarchies (Kirch 1984; Nero 1990; Earle 1991). Ngermid continues to be an important village, and today is one of the tied Ngerkldeu villages that comprise the Koror paramount chieftaincy under Ibedul.

A Yapese oral historian recounted (with key passages indicated in bold):

The Yapese were industrious and started to look elsewhere for a new form of currency. There were two men who went to Palau, where they found a beautiful white stone. This very first expedition was led by Fatha'an and Angumang, and were trips for Rull and Tomil, for Fatha'an was from Ngolog [Rull] and Angumang from Tomil. During this expedition they found the limestone islands and a place called Ramith; that's where they started to make some kind of medium of exchange. There they made the stone pieces into a number of different shapes, including the shape of a fish. Then finally it was full moon. They looked at the full moon, and then made something in that shape. But they had a problem carrying the stone, so they put a hole in the middle to make it easier to carry.

Fatha'an and Angumang were both navigators, and they were competing to bring money back to Yap. They worked in the quarries they found in the rock islands, working during the quarrying and shaping of the pieces of stone money. And Fatha'an finished first, so Angumang told him, 'why don't you take the ones over first?' So Fatha'an set out from Ngeremdiu, and started for Yap. Fatha'an being Yapese, and knowing Yapese ways, knew that it was more than likely that Angumang would use magic to make a typhoon to kill him while he was travelling on the ocean, so that he would not be able to make it to Yap. So instead, as he was travelling north, when he came to some islands he went into them and hid. And the place where he hid is called Ramith, Yapese for 'the place of hiding'. And several days later the typhoon came. And seven days later, after the typhoon, Angumang sailed for Yap, and there were heavy seas. But Fatha'an didn't move, as he knew that Angumang would sail, so Angumang came and passed Fatha'an. Then Fatha'an created a typhoon for Angumang, so that the gales and waves were high, and split the canoes into pieces, and some of the rafts carrying the stones sank, and other rafts were separated from the canoes. But Angumang was able to bring some pieces on his rafts trailing after his canoes to Yap.

Then a little later Fatha'an came behind, and he collected some of the stone money still attached to rafts floating on the water, left behind by Angumang. So he added some of Angumang's money to his own, and proceeded to Yap. And he came very slowly, for he was towing a lot of stone monies on the rafts.

When Angumang arrived on Yap, people asked what had happened to Fatha'an. And he said that he must have died on the way to Yap. And Fatha'an's parents and the people of Rull started mourning. And it was several months later that Fatha'an came, pulling a lot of stone money on rafts. It was night time when he arrived, and he came into the harbour here, at Nelil, then went up the mangrove channel and hid among the trees. And that place also is called Mamith, or hiding place. There are two places called Mith, the one in Palau, and the one in Yap called Mamith. So before dawn Fatha'an went to 
his parents' house and woke them up. The parents turned around, saying, stop making fun of us, our son died a couple of months ago. No, he said, this is Fatha'an. He then told them what had happened, so they all gathered together and cried. So he was instructed by his father to take all the stone money to Balabat [the high village of Rull] early in the morning. The father went to tell all the people that Fatha'an had returned, for the people believed he had been lost at sea. And that is how Ramith was named.

And when the Yapese first went on expeditions to quarry rocks in Palau to make their money, there were fights. So the Yapese found some caves, and went there to protect themselves from attack. The Palauans call these yii.

During a later trip, in order to make peace, the chief of Rull made a present to the chief of Palau; he gave one of the Yapese money beads to Ibedul of Koror to buy a quarry site. The bead money, of the type called Churwoo, was from Yap, [he didn't know where they got it]. As there were two chiefs of Palau, so two monies were given. These two monies, which were given, Tabremdiu [Point of Ngeremdiu] and Beluulechab [Yap], were the biggest of all Palauan monies, so they could purchase the gogyal [rock islands], of Tabremdiu and Ramith. The money was used to buy the rights to take rock from Tabremdiu [a site in the rock islands south of the island of Koror]. The second money was presented to Palau by the chiefs of Gagil, from Gachepar. There were two gifts: one from Balabat [Rull] to Koror, the other from Gagil to Melekeok. The Palau chiefs didn't mind selling the rights to quarry in some of the gogyal, as there was no one living there. And that's when the disputes between Yap and Palau were settled.

And there were a number of expeditions between Palau and Yap after the one made by Fatha'an and Angumang, and before the Europeans came. And during the exchanges the people would help each other. There was a particular family of some influence, and the women of this family, the highest clan, helped the Yapese people by providing food for their living. And in return the men helped the family by building houses, or stone platforms for houses.

... During the time of Angumang and Fatha'an, there were no men from the outer islands on the trips. Because these two were the navigators. But during the later expeditions some of the men from the outer islands were invited. Later when they made expeditions they asked the outer islanders to join, which is their sawei [their path].

... And ever since then, when the Westerners came, they began using the ship to transport stone money to Yap. But those that came by canoe earlier are of higher value.

The chiefs later closed the channels of collecting stone money in Palau, for two reasons. The first is that if they allowed people to go there and bring so many pieces of money on the island, their value would go down. And the other reason is that then there were ships that went to Palau carrying the stone monies back, and these pieces were bigger than before, but there was no danger in getting them. The largest piece of money brought to Yap, now on Rumung, was brought by ship, and the traditional leaders during that time said this is a bigger piece, but there is a smaller piece which was gotten by hardship taken by canoes, so the smaller one is more valuable than the bigger piece. There were so many pieces it was hard to keep value in the whole system, so they stopped the quarrying.

\section{Discussion of the oral histories: Yap}

I have shown in bold key texts to be considered in trying to unravel the time-depth issue for Yapese quarrying in Palau. While the identification of Ramith, or Ngermid, is an important time marker, its meaning could relate to Ngermid either as a Child of Chuab, or as a renged village of Koror. Unfortunately, the narrative's identified sequence of events, as currently recorded, does not solve the problem. The historian indicated that quarrying began at Ramith led by men of Fatha'an of Rull and Angumang of Tomil. The historian noted that there was a time lapse and period of fighting before later expeditions. To end the fighting and establish quarrying rights, 
the Chief of Rull presented Ibedul of Koror the money Tabremdiu, while the Chief of Gachepar presented the named money Beluulechab to the Reklai, the chief of Melekeok. The shift in participation from Tomil to Gachepar may also signal a time lapse. While the sequence is clear, there is no apparent indication of the antiquity of the earliest quarrying voyages.

\section{Palauan histories}

Ngermid

Interviews with the elders of Ngermid village confirmed the Yapese history that the village's name is Yapese in origin, and that its naming had to do with the Yapese who hid there while on a stone-money quarrying voyage.

While the origin of the name is not generally known in Palau, it is not hidden or secret, and can be discussed. When the Yapese first came they were quarrying for stone money at the rock islands on the Airai side, but they were fought there. So they came over to the rock islands by Ngermid, where they hid in a cave, which is not far from the main road. And then Bilung heard that the Yapese were there, and told her people to bring them to her, and she cared for them. And then they brought a money from Yap to give to Ibedul, the one called Tabremdiu, which was given from Rull to Idid [the Koror clan of which Ibedul and Bilung are the highest male and female titles respectively], which is why they are related today. It was at least the second or third quarrying voyage when the payment was made to Ibedul.

This account from elders of Ngermid adds information that before quarrying in Ngermid, Yapese had been quarrying on islands in Airai, and there were at least two to three voyages before the Yapese from Rull presented a bead money named Tabremdiu to Ibedul of the Idid clan of Koror.

\section{Palau Society of Historians}

The Palau Society of Historians also began its discussion of early linkages to the outside world with the Yapese quarrying of stone money in Palau. It provided information about other islands as well.

The link, from the time long ago, had to do with the quarrying of balang [stone money]. They came, but it was a bit difficult that taking balang from Koror, for they belonged to Koror. And there was also a link with Melekeok, for Reklai bought the island Toi er a Bisch [Channel of the Wild Taro] so they could take their stone money there. And that happened for perhaps twenty or twenty five years. There was a treaty, which gave them the path to come to Palau. And this was the story of Ibedul and Reklai. For it was Ibedul who controlled the chelebacheb [rock islands], which was well explained. So they [the Yapese] should have been the people of Ibedul. But the reason that Reklai bought a rock island is that he was leader of the other heaven, and it would be bad for him not to have his hand on the spear as well. So they tied the relationship between Yap and Palau, those two heads. That was before the time of the Westerners, before the time of the Spanish, long before that. And the Yapese came by canoe to take the balang back to Yap on their rafts [trailing behind the canoes].

But that time was difficult, for it was still a time of warfare in Palau. And so the Yapese were afraid. And it was during that time that Reklai and Ibedul were bringing together their peoples. And so the Yapese catered to those two leaders. And they came to Palau to make those large stone monies. And that's why Yap and Palau had one heart. And at that time Yap was also divided, and one side came, that of Rull, which came to Koror. And the other came to the small villages that went to Melekeok. And that's why, a few months ago, we went from Melekeok to visit in Gachpar, in Yap, for several weeks. And it was the relationship of the stone money, which was the basis for this visit. For the second group that came didn't have a way of working with those that were already here from Yap, for they were split. That's 
why they went to find Reklai, and why he bought that rock island in front of Airai, so that the second group of Yapese could take their money there. So today we and those from Yap are linked together by that money.

And that was the rule of Palau in the past, that of hospitality, of taking care of people. It was the law, that the chief should humbly receive them, taking them to heart, to make them his people. It was the chief who took in the outsiders. And there is a chant, which records this.

And there is also the story of another stone money voyage, that of a chief of Melekeok who came to take stone money. He came and quarried the money and was on his way to Yap when he was struck by a storm. And he was drifted ashore at Ngchesar, but then he was taken to Melekeok where he became the third chief there, holding the title of Ngirkungil. Yes, he was Yapese, but he was given a high chiefly title in Melekeok. And this was before the ships had first come ...

Because those that came from the two heavens of Yap couldn't come and work together here, those people of Tomil and Rull. And that's why they went to Reklai and begged of him for help. And during that time Ibedul and Reklai could communicate privately through their messengers. And that Ngirkungil took some money and gave it to Ibedul, saying, these are my people, please let them come and take their stone money here. So he sold them that rock island in front of Airai, so they could quarry there. That was a long time ago, taking stone money a very long time ago.

\section{Discussion of the oral histories: Palau}

The first oral history from Ngermid speaks of the earliest quarrying voyages, first to Airai and then, after fighting, to the Rock Islands by Ngermid. It states that following at least two or three voyages, the Yapese from Rull presented Ibedul with a money named Tabremdiu in return for the rights to quarry stone money. This history may be compared with the short history at the beginning of the chapter. Other oral historians referring to this site gave the name and history of the name 'Omis'.

The second oral history was provided by members of the Palau Society of Historians, speaking for Palau. They referred to Yapese quarrying voyages at the time that the two paramount chieftaincies of Koror and Melekeok were each being consolidated, before the arrival of European ships. Once again they recounted Rull's presentation of Tabremdiu to Ibedul and Gachepar's presentation of a money to Reklai for rights to quarry the stone money. This account provided greater details of Reklai's purchase of a Rock Island so that both chieftaincies could be represented in the relationships with the two villages of Yap.

\section{Differing practices concerning time}

A challenging but potentially productive difference between the expert practices of oral historians and archaeologists is the way in which they address and relate to time. Archaeological research emphasises chronologies established by thorough examination of carefully sampled and controlled stratified data, with date ranges proposed in a calendar time sequence. Western time is linear and is generally expressed within standard $\mathrm{BC}$ or $\mathrm{AD}$, or $\mathrm{BP}$ (before present) categories. In contrast, Palauan oral histories focus on mnemonic devices to anchor and help verify the history given by respected historians. These devices range from places, titleholders or individuals involved in important events, to physical signs (i.e. landscape markers, stones, money pieces, certain plants, bas-relief carvings depicting histories) or performative genre (i.e. chants, songs, dances) that refer to events. This material is also 'sedimented' in a multi-layered way that is metaphorically similar to archaeological excavation units.

While it is common for an account to include markers referring to the relative order of events, the focus is on social relationships and places, and not calendar time. Information on the 
relative sequence of events may be of use, but may be ambiguous if the attempt is to identify a specific time period. More important, while Micronesian oral historians may identify a narrative's relative sequence of events, it is just as common for them to omit events in the sequence. Because oral histories, and other types of knowledge, are important components of power, the historian will often not divulge the entire story at one sitting. Hence, the presentation of a full sequence of events in any one narrative should not be expected. With diligence and careful analysis of multiple accounts, the skilled oral history researcher may be able to identify missing parts and frame further questions in order to piece together a complete sequence (see Petersen 1994).

As would be expected of experts, respected oral historians in Palau will very carefully identify areas of which they do not have any knowledge. They also judiciously consider what information they do hold for its relevance. The oral historians may be able to search their deeper knowledge of the narratives, and perhaps some of the kelulau histories they retain, to provide further insights into the early period of Yapese quarrying. This would assist in an issue that is still unresolved using archaeological methods and approaches.

\section{Bringing together oral historical and archaeological approaches}

The Micronesian Historic Preservation Offices (HPO) were originally established through the extension of a number of federal programs to the US Trust Territory of the Pacific Islands. During the region's transition to freely associated status, reduction of a block grant threatened the continuation of the Historic Preservation Offices. The offices in the newly freely associated nations of the Federated States of Micronesia, Palau and the Marshall Islands lobbied strongly and successfully with the US Congress for continuation of federal funding. The Micronesian $\mathrm{HPOs}^{8}$ are still closely linked to American archaeological practices, including the challenges and opportunities created by the 1990 passage of the Native American Graves Protection and Repatriation Act (NAGPRA). Issues of the historical veracity of oral traditions have recently been strongly debated within that context. Mason (2000) analysed the challenging $(n=4)$ and supporting $(\mathrm{n}=7)$ arguments for the incorporation of oral traditions in archaeological theory or practices from Native American perspectives. His conclusions focus on the dilemma concerning the relationships between calendrical time and relative chronologies and tendencies of oral societies to achronicity. He also recognises the dangers of what he calls 'cherry picking in a minefield' (Mason 2000:260). Mason concludes that the two epistemologies are fundamentally disparate, with his careful review of the arguments providing a foundation for future discussions.

Rock Island studies

The period of my first research in Palau (1979-1984) partially coincided with archaeological studies by the Center for Archaeological Investigations (CAI) of Southern Illinois University at Carbondale. I was working through Koror State and the archaeologists were based at the Bureau of Arts and Culture (BAC). It was impossible to schedule joint site visits, partly due to our positions in different agencies, but also because of time constraints for the work undertaken. Both the CAI and Koror State teams collected oral histories from living historians. The Koror State team focused on those titleholders or specialists whose traditional rights and responsibilities for sections of the Rock Islands continued into the present. This mainly included the villages of Ngerchemai, Ngerbeched, Ngerkebesang and Ngermid, while working with all the titleholders of Ngarameketii and Rubekulkldeu as appropriate.

As Tellei et al. (2005:11) noted, clan, lineage or family histories affect access to traditional information. The familial links of the BAC staff in some cases differed from those of Koror State. It appears that CAI might have recorded oral histories from historians linked to Koror 
and perhaps from descendants of former Rock Island villages whose people migrated elsewhere. If so, such histories could provide important insights into the dynamics of the out-migrations, as the resettlements of clans and villages established new allegiances in other states. As these oral histories and identifications of the Rock Island villages were conducted nearly three decades ago, they should be re-verified.

Verification is often a long-term project. In 1983-1984, the elders wished to make a map available to the general public that accurately recorded place names in the Rock Islands. My 1987 doctoral dissertation included a draft of the Koror map, although the included Rock Island place names were not immediately verifiable. Years later, establishment of the Koror State Rangers under the direction of Adelbert Eledui, and now Ilebrang Olkeriil, allowed this important verification to be appropriately completed. This map is now available (at different levels of precision) through the Palau Visitors Authority and the Rock Islands Southern Lagoon Management Area (Figure 3).

\section{Study of early Yapese stone-money quarrying in Palau}

In the early 1990s, I sought a different type of cross-validation of oral histories and their potential time depth by approaching the Yap HPO with which I had been working since 1979. With its assistance and the provision of staff to translate and transcribe, we were able to interview recognised elders who spoke for Yap-Palau stone-money quarry stories and could appropriately transmit them. Following Yapese protocols and state law, the Council of Pilung ultimately approved a Palau-Yap Linkages paper for presentation and publication (through the Yap HPO). I also conducted additional interviews with elders in Palau and with the Palau Society of Historians. The resulting paper was provided to the Palau and Yap HPOs and the Belau National Museum for use by local researchers. The experts quoted above are in this manuscript.

At the time, we did not have archaeological dates to use in considering the relative time period/s in which these stories took place. It was solely an oral history project working with Yapese and Palauan elders and there was no attempt to establish a timeline. In 1992, I simply noted that the identification of Ngermid did not resolve the ambiguity of potential dating of the earliest Yapese quarrying activities.

\section{Recent archaeological research on Palau-Yapese stone money}

There have been two recent doctoral studies and subsequent publications concerning the PalauYap stone-money exchange, by University of Oregon archaeology graduates Descantes (2005) and Fitzpatrick (2003). The two archaeologists used the term ethnohistory somewhat differently and both valued oral histories. The two differing approaches to the use of oral histories (or ethnohistorical data) provide an excellent foundation for a discussion of current practices.

Descantes' thesis concerned the development of the exchange relationships between Yap and Ulithi. While focused on sawei relationships between the villages of Yap Island and the Outer Islands of Yap, he included several sections considering Yapese stone-money quarrying. Descantes (2005:16) used the term ethnohistory, which he defined, in contrast with archaeological history, as:

an ethnological study based on historical documents and indigenous histories, lends non-material contextual information about island interactions of a short time span while archaeological evidence, on the other hand, provides a representation of exchange practices in much longer time duration.

Rather than prehistory, he used the term protohistory, which he defined as: 'the time segment between European discovery and the settlement of the island's societies' (Descantes 


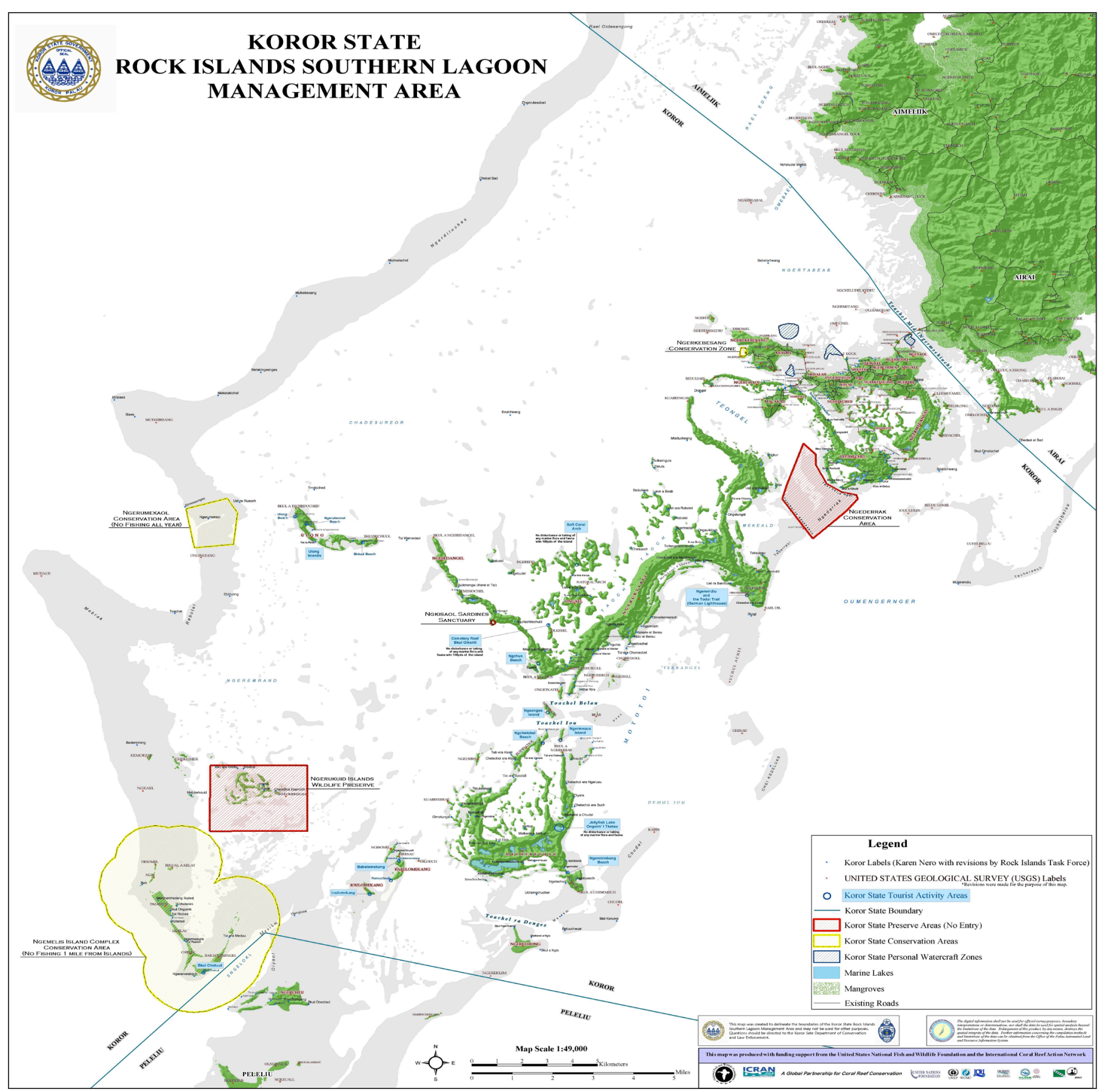

Figure 3. Map of the Koror State Rock Islands-Southern Lagoon management area.

2005:29). For Yap, he identified this as the period between AD 1525 and AD 1843. Descantes carefully analysed historical documents from the 16th century onwards, including the writings of early visitors, missionaries and traders, and the detailed 19th century scientific observations the first 'ethnographic accounts' of the Polish naturalist Kubary (Descantes 2005:29-38).

In his discussion chapter, while considering the 'Epistemological Challenge ... [of] the integration of archaeological and ethnohistoric records involved in his exchange model', Descantes noted (2005:95): 
European contact is an important boundary point because not only major cultural transformations ensued, but also because this is when Western Carolinian cultures entered the European ethnohistorical records. The latter did not have a profound effect on the sedimentation of the archaeological record, but it did influence the ethnohistoric records and methodology for integrating both records. The last 400 years of the exchange model is a combination of both records. My construction of the pre-contact period relied, but for a few cases, on the archaeological records alone. I did this for the obvious reasons that the European-made ethnohistoric record was more accessible and understandable to me. While I relied little on indigenous oral histories for explaining the archaeological patterns, I did use it to frame the research ...

Protohistoric period interpretations, which depended upon archaeological and European-produced ethnohistoric data, were richer than either record alone. I used both records in a complementary fashion to focus on the problem of change.

Descantes (2005:95) chose to limit his use of indigenous oral histories to frame his research, provide leads for sites to be investigated or to add 'details of practice and the mentalities of the people'.

It appears that Descantes did not have access to, or recognised he did not have the specialised expertise to work with, contemporary oral historians. He also recognised that those oral histories of the sawei earlier recorded by anthropologists had been of historical, not modern practices. He used the term ethnohistory to refer to those indigenous histories recorded by anthropologists, perhaps marking their transformation in the process of writing such histories of the sawei system. Descantes (2005:29):

Anthropologists recorded ethnohistory from their informants who were taught by older relatives and friends about the formalized tribute system. Therefore, the ethnographic data represent how the system was meant to operate in the nineteenth and twentieth centuries.

Without access to oral histories that had been collected at the time of the sawei practices Descantes (2005:95) would consider contemporaneous, he followed Gosden (1996) in considering these as mythno-histories or ethnohistories, identifying specifically myths, histories and genealogies as:

... partial and distorted accounts of the past made to shore up particular interests and undermine others, in exactly the same way as other histories are, but they also contain information about past events and the cultural schemes through which events were appreciated.

Clearly, Descantes recognised the complexity and different epistemologies involved in working with oral historical as opposed to archaeological knowledge. He undertook the challenge of integrating several types of ethnohistorical accounts, although recognising that the oral histories could not have been recorded at the time of such developments. It appears that he did not work with contemporary oral historians from Yap or Ulithi, but relied on earlier anthropological records of oral histories. While he chose not to use recorded indigenous oral histories for the most part, he recognised their potential for other scholars to pursue. Descantes' (2005:96) thoughtful conclusion pointing to the value of closer work with 'ethnohistorians and native peoples' foregrounds my understandings, although his framing of indigenous oral histories as 'myth-history' and 'ideology' are worthy of debate:

The integration of mytho-history in my interpretations about the past is only as accurate as my understanding of the texts. Despite these challenges, I believe this rich data set of ideology is a potential source worthy of closer investigation by archaeologists in collaboration with ethnohistorians and native peoples. (emphasis added) 
The second PhD dissertation, by Scott Fitzpatrick (2003), is an archaeological investigation of the Yapese stone-money quarrying in Palau. In his chapter on oral traditions, ethnohistory and ethnography, he attempted to broaden the ways in which oral traditions might be used to help understand the origins and transformation of stone-money production and exchange processes, and in his acknowledgements, he recognised the support of the chiefs and governors of Airai, the chiefs of Ngermid, the Palau Society of Historians, the Palau Cultural Advisory Board, and Kathy Kesolei. Like Descantes, Fitzpatrick began with ethnohistoric accounts generally drawn from early European explorers, travellers and traders. His second section, entitled 'Oral traditions' and ethnographic observations, consists primarily of paraphrased or verbatim quotations of oral histories recorded (and excerpted) by Nero in the 1990s and one early account by Müller (1918, quoted by Gilliland 1975:188), from which Fitzpatrick took the title of his thesis. For the most part, the oral histories were simply quoted to provide a descriptive background of the early quarrying visits, supported by an ethnographic observation by Hunter-Anderson (1983:19) that the early relationship between Koror and Rull might explain the 1980s place of residence of Palauans in Yap. Fitzpatrick's use of the term ethnographic observations presumably also included those referred to in the following sections summarising accounts and photographs from early travellers, and traders ${ }^{10}$ and scholars interested in how stone-money pieces were valued (strongly based on the work of de Beauclair 1971). He also drew on acknowledged scholars such as Kubary, Alkire, Lingenfelter, Friedman, Hezel and Lessa in a comprehensive review of relevant recorded oral traditions, traveller and trader accounts and the work of recognised predominantly socio-cultural anthropologists. Fitzpatrick returned to the oral histories and ethnographic accounts in his analysis of Yapese-Palauan interactions, and concluded that (2003:96):

According to oral traditions and ethnographic accounts, the most extreme example of subservience within the three groups (Palauans-Yapese-Outer Islanders) of these exchange networks appear to have been the Yapese in their dealings with the Palauans. As noted previously, Palauan oral traditions state that the Yapese were subservient to the Palauans and worked building stone pathways, foundations, and other infrastructure projects in return for quarrying rights.

This is somewhat misleading, in that the accounts he referred to of the Yapese (and Outer Islanders) working on infrastructure projects in Palau were based on quotations from Kubary's late 19th century and Müller's early 20th century observations, not on the oral traditions. Returning to the oral histories, he then described more equal exchange relationships and cognate place names and titles from the two island groups, which he next discussed. Overall, Fitzpatrick used oral traditions to provide a descriptive introduction to frame his study.

My one concern in reading the thesis was that in the oral traditions section, the quoted oral histories were excerpted from an early version of my research paper on the Yap-Palau early quarrying relationships without seeking my permission, the normal academic protocol for using lengthy quotations. Nor in his thesis did he acknowledge working with any of the Yapese elders, which raised concerns about whether the Yapese were aware of and approved of the use of the materials, although the excerpts were drawn from a paper approved by the Council of Pilung and left with the Yap and Palau Historic Preservation Offices. In the absence of any communication from Fitzpatrick, I made arrangements to meet with my Yapese colleagues and appropriate elders and was happy to confirm that the Yapese elders were aware of and supported the use of the materials in support of subsequent proposals under the relevant Palau and Yap offices.

On further reflection, I appreciated that Fitzpatrick did not attempt to personally collect the oral histories. Especially at a doctoral level, it is difficult enough to master and demonstrate the 
appropriate level of archaeological theoretical and methodological expertise, much less that of a second discipline such as oral history, with its own protocols, research methods and analytical techniques. Any true integration of the epistemologies and methods of archaeological and oral historical expertise does not appear feasible for an individual's doctoral research. Nevertheless, normal academic and indigenous protocols must be identified and followed. I suggest that scholars take care in using written excerpts of oral histories and check these where possible with the collector of the histories and the oral historians who speak for the information.

\section{Lessons from recent and current collaborative work in Palau}

The work of archaeologists and oral historians differ epistemologically and in disciplinary preparation. The two fields both require long training periods and include specialist techniques and theoretical understandings. Both are site specific, although the time needed on site may significantly differ. Data collected by archaeologists generally requires some laboratory analysis. This is followed by analysis by the archaeologist and interpretation and preparation of the data. Information from oral historical accounts, collected in sequential interviews over months and sometimes years, must be reviewed, transcribed and often translated into a common language such as English. These accounts require verification by the persons/titles with the original source and appropriate local experts.

Recent studies recognising the importance of working with oral historians contribute to work between our sub-disciplines, reducing theoretical, methodological and terminological differences. Our success as we further refine their theoretical frameworks and methodologies will depend on our relationships with oral historians. With regard to oral histories, we must foreground the living knowledge of the oral historians as that passed on to future generations; it is the living tradition rather than any written portions of such knowledge that are authoritative. While recognising that oral histories will be recorded, transcribed, translated and written, we must acknowledge the effects of each transition. While hoping for greater insight through collaboration, we cannot expect that the knowledge collected through such different approaches will necessarily support, refute or provide mutually recognised value to the research. Finding ways to join the separate paths to knowledge that are followed by oral historians and archaeologists has been difficult in the past. Forging a shared path will involve constant negotiation and engagement with different types of knowledge.

One model of successful collaborative research was the incorporation of oral historical documentation by the Pacific Resource Institute (Tellei et al. 2005) in the Palau Compact Road cultural resource management investigations. ${ }^{11}$ The Palau Historic Preservation Office began in the 1990s to ensure the active collaboration of oral historical and archaeological research in Palau. The collaboration was written into the Compact Road project from the outset to provide significant data and to ensure both the intangible and tangible cultural remains were appropriately mitigated. This supported frequent consultation, joint analyses and co-publication by archaeologists and oral historians. Following this model, rather than trying to bridge very different epistemological and methodological approaches, a team approach with active work towards interdisciplinary publications that highlight each other's strengths and the issues encountered will move us forward. 


\section{Notes}

1. In this section, those definitions in quotations have been taken from the Oxford Dictionary of English, 2nd edition.

2. During my five years residence in Palau, I also worked closely with the Belau National Museum, the Palau Bureau of Arts and Culture (once named the Historic Preservation Office) and the Palau Society of Historians. Two families welcomed me as their 'ngalek' or child, and have provided invaluable guidance and support throughout the years.

3. The male and female titles and councils have complementary responsibilities in managing village production and political relationships. Women's work centres on the customary symbolic and economic support of the male titles/councils by managing the feasts required to confirm the taking of a title or other major events. The male titleholders and councils present the political voice of the clan/village. Both types of councils are supported by age-graded and gendered cheldebechel (clubs). Through participating in this dispersed system of governance, members learn the structured relationships between clans and villages through practice. At most events, men and women, and often boys and girls, perform appropriate chants and dances commemorating major historical events, again ensuring wide distribution of historical knowledge.

4. I was permitted to use some of these materials as part of my doctoral thesis.

5. Under US trust territorial administration, the former district villages were recognised as municipalities which, in 1981, were replaced by state governments. In Koror, the traditional male chiefs generally held the highest municipal or state positions. During the Koror Constitutional Convention (1983-84), half the representatives were drawn from traditional leaders, and the remaining were elected (in many cases those elected would be likely to hold titles in the future). In recent years, both in amended constitutions and in daily practices, there are increasing separations between traditional and elected leadership, and the election of government officials.

6. An earlier offer to record the Koror histories was not accepted.

7. Beads and ring pieces made of Tridacna were used in many parts of the Pacific.

8. In Palau the name was changed to the Palau Bureau of Arts and Culture (BAC).

9. It appears Fitzpatrick was following Vansina’s (1985) early nomenclature of oral traditions as accounts of events not personally witnessed.

10. Including traveller and trader accounts as ethnographic accounts stretches the usual requirements of scientific observation and analysis for an account to so qualify.

11. Compact Road cultural resource management work was conducted by International Archaeological Research Institute, Inc. out of Honolulu under contract to the US Army Corps of Engineers, Pacific Ocean Division.

\section{Acknowledgements}

Over the past two decades, support for this research has been received from a number of sources, including the University of California, Berkeley Institute of Social Change, the National Institute of Mental Health, Koror State Government, the Robert F. Gumbiner Fund of the University of California, Irvine and the National Science Foundation. Recent research trips were funded by the University of Auckland and the University of Canterbury in New Zealand.

I especially acknowledge the present and former Palau Ministers of Community and Cultural Affairs Faustina Rehuher and Senator Alexander Merep; oral historian Fermina Brel Murray; anthropologist Katharine Kesolei; archaeologists Rufino Mauricio, the late Rita Olsudong and Jolie Liston; the Palau and Yap Historic Preservation Offices; the Palau Society of Historians and the male and female elders of Palau and Yap who have patiently shared their knowledge with us and provided training in the protocols of local historical research. I also thank the support of the Koror State Government staff members. 


\section{References}

Biersack, A. 1991. Clio in Oceania: Toward a historical anthropology. Smithsonian Institution Press, Washington.

Burley, D.V. 1998. Tongan archaeology and the Tongan past, 2850-150 B.P. Journal of World Prehistory 12(3):337-392.

Chaves, K.K. 2008. Ethnohistory: From inception to postmodernism and beyond. Historian 70(3):486-513.

Clark, G., Anderson, A. and Wright, D. 2006. Human colonization of the Palau Islands, western Micronesia. The Journal of Island and Coastal Archaeology 1(2):215-232.

Comaroff, J. and Comoroff, J. 1992. Ethnography and the historical imagination. In: Comaroff, J., Bourdieu, P. and Bloch, M. (eds), Studies in the ethnographic imagination, pp. 3-48. Westview Press, Boulder.

de Beauclair, I. 1971. Studies on Botel Tobago, and Yap. In: Tsuk'uang, L. (ed), Asian folklore and social life monographs, pp. 183-203. Orient Cultural Service, Taipei.

Dening, G. 1966. Ethnohistory in Polynesia: The value of ethnohistorical evidence. Journal of Pacific History 1:23-42.

Dening, G. 1980. Islands and beaches: Discourse on a silent land: Marquesas 1774-1880. The Dorsey Press, Chicago.

Dening, G. 1991. A poetic for histories: Transformations that present the past. In: Biersack, A. (ed), Clio in Oceania, pp. 347-380. Smithsonian Institution Press, Honolulu.

Descantes, C. 2005. Integrating archaeology and ethnohistory: The development of exchange between Yap and Ulithi, Western Caroline Islands. British Archaeological Reports International, Volume 1344. Archaeopress, Oxford.

Earle, T. 1991. The evolution of chiefdoms. In: Earle, T. (ed), Chiefdoms: Power, economy and ideology, pp. 1-15. Cambridge University Press, Cambridge.

Ericsson, K.A., Charness, N., Feltovich, P. and Hoffman, R.R. 2006. The Cambridge handbook of expertise and expert performance. Cambridge University Press, Cambridge.

Fitzpatrick, S.M. 2001. Archaeological investigations of Omis Cave: A Yapese stone money quarry in Palau. Archaeology in Oceania 36(3):153-162.

Fitzpatrick, S.M. 2002. A radiocarbon chronology of Yapese stone money quarries in Palau. Micronesica 34(2):227-242.

Fitzpatrick, S.M. 2003. Stones of the butterfly: An archaeological investigation of Yapese stone money quarries in Palau, Micronesia. Unpublished PhD thesis, Department of Anthropology, University of Oregon, Eugene.

Gilliland, C.L.C. 1975. The stoney money of Yap: A numismatic survey. Washington, DC. Smithsonian Institution Press.

Gosden, C. 1996. Transformations: History and prehistory in Hawaii. Archaeology in Oceania 31(3):165-172.

Gumerman, G.J., Snyder, D. and Masse, W.B. 1981. An archaeological reconnaissance in the Palau Archipelago, Western Caroline Islands, Micronesia. Center for Archaeological Investigations, Southern Illinois University, Carbondale.

Hambruch, P. 1932. Ergebnisse der Sudsëe expedition, 1908-1910, II, B, 7. In: Thilenius, G. (ed), Ponape, Volume 1. Friederichsen, De Gruyter, Hamburg.

Hambruch, P. 1936. Ergebnisse der Sudsëe expedition, 1908-1910, II, B, 7. In: Thilenius, G. (ed), Ponape, Vol. 2. Friederichsen, De Gruyter, Hamburg.

Hanlon, D. 1988. Upon a stone altar: A history of the island of Pohnpei to 1890. University of Hawai' $\mathrm{i}$ Press, Honolulu.

Hunter-Anderson, R.L. 1983. Yapese settlement patterns: An ethnoarchaeological approach. Pacific Studies Institute. Series 3. 
Johannes, R.E. 1981. Words of the lagoon: Fishing and marine lore in the Palau district of Micronesia. University of California Press, Berkeley.

Kesolei, K. 1977. Cultural conservation: Restrictions to freedom of inquiry: Palauan strains. Paper presented at the Association of Social Anthropology in Oceania, Workshop on The Role of Anthropology in Contemporary Micronesia. Trust Territory of the Pacific Islands.

Kirch, P.V. 1984. The evolution of the Polynesian chiefdoms. Cambridge University Press, Cambridge. Liston, J. [1999] 2007. Archaeological data recovery for the Compact Road, Babeldaob island, Republic of Palau. Historic preservation investigations, Phase II. Volume V: Lab analyses, syntheses, recommendations. Prepared for the US Army Corps of Engineers, Pacific Ocean Division, Hawai i International Archaeological Research Institute, Inc., Honolulu.

Liston, J. 2009. Cultural chronology of earthworks in Palau, western Micronesia. Archaeology in Oceania 44(2):56-73.

Liston, J. 2010. Archaeological monitoring and emergency data recovery for the Compact Road, Babeldaob island, Republic of Palau. Historic preservation investigations, Phase III. Volume XII: Lab analyses, discussion, syntheses. Draft report prepared for US Army Corps of Engineers, Pacific Ocean Division, Hawai' i. International Archaeological Research Institute, Inc., Honolulu.

Mason, R.J. 2000. Archaeology and native North American oral traditions. American Aniquity 65(2):239-266.

Masse, W.B. 1984. Rock Island village settlement systems: A preliminary report on the analysis of archaeological remains in the coralline limestone ('rock') islands, Republic of Palau. Centre for Archaeological Investigations, Southern Illinois University, Carbondale.

Masse, W.B., Liston, J., Carucci, J. and Athens, J.S. 2006. Evaluating the effects of climate change on environment, resource depletion, and culture in the Palau Islands between AD 1200 and 1600. Quaternary International 151:106-132.

Masse, W.B, Snyder, D. and Gumerman, G.J. 1984. Prehistoric and historic settlement in the Palau Islands, Micronesia. New Zealand Journal of Archaeology 6: 107-127.

Mauricio, R. 1992. A history of Pohnpei history or Poadoapoad: Description and explanation in recorded oral traditions. In: Rubinstein, D. (ed), Pacific History: Papers from the $8^{\text {th }}$ Pacific History Association Conference, pp. 351-380. University of Guam Press and Micronesian Area Research Center, Mangilao.

Meleisea, M. 1987. The making of modern Samoa: Traditional authority and colonial administration in the modern history of Western Samoa. Institute of Pacific Studies of the University of the South Pacific, Suva.

Merwick, D. 1994. Dangerous liaisons: Essays in honour of Greg Dening. In: Mayne, A (ed), Melbourne Monographs. University of Melbourne, Melbourne.

Morphy, H. 1991. Ancestral connections: Art and an aboriginal system of knowledge. University of Chicago Press, Chicago.

Morphy, H. 1995. Landscape and the reproduction of the ancestral past. In: Hirsch, E. and O'Hanlon, M. (eds), The anthropology of landscape, pp. 184-209. Clarendon Press, Oxford.

Müller, W. 1918. Ergebnisse der Sudsëe expedition, 1908-1910, II, B, 2. In: Thilenius, G. (ed), Yap, Vol. 2. Friederichsen, De Gruyter, Hamburg.

Nero, K.L. 1987. A cherechar a lokelii: Beads of history of Koror, Palau, 1783-1983. Unpublished PhD dissertation, Department of Anthropology, University of California, Berkeley.

Nero, K.L. 1990. Linkages betwen Yap and Palau: Towards regional histories. Paper presented at 8 th Pacific History Association Conference, Guam.

Nero, K.L. 2002. Keate's Account of the Pelew Islands: A view of Koror and Palau. In: Nero, K.L. and Thomas, N. (eds), An account of the Pelew Islands: George Keate, pp. 7-25. Leicester University Press, London.

Ohnuki-Tierney, E. (ed), 1990. Culture through time: Anthropological approaches. Stanford University Press, Stanford. 
Palau National Committee on Population and Children (CoPopChi). 1997. Population and development: Toward a Palau national policy for sustainable human development. Office of the President: Republic of Palau, Koror.

Parmentier, R.J. 1987. The sacred remains: Myth, history, and polity in Belau. University of Chicago Press, Chicago.

Petersen, G. 1990. Lost in the weeds: Theme and variation in Pohnpei political mythology. Occasional Paper, Center for Pacific Islands Studies, University of Hawai' $\mathrm{i}$, Honolulu.

Petersen, G. 1994. Kanengamah and Pohnpei's politics of concealment. American Anthropologist 95(2):334-352.

Ritzenthaler, R.E. 1954. Native money of Palau, Publications in Anthropology. Milwaukee Public Museum, Milwaukee.

Rubinstein, D.H. 1992. Pacific History: Papers from the 8th Pacific History Association Conference. University of Guam Press and Micronesian Area Research Center, Mangilao.

Sahlins, M. 1983. Other times, other customs: The anthropology of history. American Anthropologist 85(3):517-544.

Sahlins, M. 1985. Islands of history. University of Chicago Press, Chicago.

Sahlins, M. 2004. Apologies to Thucydides: Understanding history as culture and vica versa. University of Chicago Press, Chicago.

Schwarz, M.T. 1997. Molded in the image of changing woman: Navajo views on the human body and personhood. The University of Arizona Press, Tucson.

Sheppard, P., Walter, R. and Aswani, S. 2004. Oral tradition and the creation of late prehistory in Roviana Lagoon, Solomon Islands. Records of the Australian Museum Supplement 29:123-132.

Tellei, J., Basilius, U. and Rehuher, F.K. 2005. Palau Compact Road archaeological investigations, Babeldaob island, Republic of Palau. Historic preservation investigations Phase I. Volume III: Oral history documentation. Prepared for the US Army Corps of Engineers, Pacific Ocean Division, Hawai i. Tomonari-Tuggle, M.J. (ed), International Archaeological Research Institute, Inc., Honolulu.

Vansina, J. 1985. Oral tradition as history. University of Wisconsin Press, Madison.

Voss, J.F. and Wiley, J. 2006. Expertise in history. In: Ericsson, K.A., Charness, N., Feltovich, P. and Hoffman, R.R. (eds), The Cambridge handbook of expertise and expert performance, pp. 569-584. Cambridge University Press, Cambridge.

Wickler, S.K., Addison, D.J., Kaschko, M.W. and Dye, T.S. [1997] 2005a. Intensive archaeological survey for the Palau Compact Road, Babeldaob island, Palau. Historic preservation investigations Phase I. Volume II: Area survey reports. Prepared for the US Army Corps of Engineers, Pacific Ocean Division, Hawai'i. International Archaeological Research Institute, Inc., Honolulu.

Wickler, S.K., Welch, D.J., Tomonari-Tuggle, M.J., Liston, J., Tuggle, H.D. and Grant, D. [1998] 2005b. Intensive archaeological survey for the Palau Compact Road, Babeldaob island, Palau. Historic preservation investigations Phase I. Volume I. Scope, background, results, excavation, and recommendations. Prepared for the US Army Corps of Engineers, Pacific Ocean Division, Hawai i International Archaeological Research Institute, Inc., Honolulu.

Wilding, J.R. and Valentine, E.R. 2006. Exceptional memory. In: Ericsson, K.A., Charness, N., Feltovich, P. and Hoffman, R.R. (eds), The Cambridge handbook of expertise and expert performance, pp. 539-552. Cambridge University Press, Cambridge. 